\title{
Contrastive analysis of the semantic relations of connectors in argumentative texts in English and Albanian
}

\author{
Manjola Lubishtani ${ }^{\text {a } *}$ (iD) \\ ${ }^{a}$ University of Prishtina "Hasan Prishtina”, Department of Albanian Language, Prishtina, 10000, Kosovo
}

\section{APA Citation:}

Lubishtani, M. (2019). Contrastive analysis of the semantic relations of connectors in argumentative texts in English and Albanian. Journal of Language and Linguistic Studies, 15(2), 508-519.

Submission Date:13/10/2018

Acceptance Date: $17 / 05 / 2019$

\section{Abstract}

The main purpose of this paper is the functional analysis and argumentation of text connectors as tools for implementation of the textual connectivity not only in the local but also global context. Given the comparative nature of this paper, we will be comparing typology and relationships expressed by the connectors in some of the argumentative texts published in the investigative journalism Project Syndicate network with their analogous versions translated into Albanian and published in the Kosovo daily newspaper Koha Ditore.

Thus, the treatment of the relationships they express will be realized by analyzing the preservation of the typology of the connectors during the translation process from the original variants in the language in which they are translated, in our case in Albanian.

Such processed data will provide answers related to the frequency of the connectors' use, their means of realization, relations expressed according to the prevalence of connectors as well as their semantic, grammatical and functional equivalency.

C 2019 JLLS and the Authors - Published by JLLS.

Keywords: Textual connectivity; connectors; typology of relationships; relative frequency; argumentative text

\section{Introduction}

By enabling realization of connectivity in both spoken and written language, connectors - being "a functional class of lexical expressions in every language" (Fraser, 1996)- take a rather important and indispensable place in structuring of a text. From a functional point of view, they enable cohesion as organizers of logical-semantic relation of the textual component segments - simultaneously serving as active catalysts of textual coherence, ensuring thereby both internal and external sustainability of any text meaning.

The main objective of research in this paper is to treat connectors and relationships they present in argumentative texts randomly selected, based on argumentation of a feature: preservation of semantic

\footnotetext{
${ }^{*}$ Corresponding author. Tel.: +383-44-895-437

E-mail address: manjolalubishtani@gmail.com
} 
typology of connectors during translation process from original version published in English in Project Syndicate ${ }^{\dagger}$ into equivalent versions published in Albanian in the Kosovo daily newspaper "Koha Ditore", which is a part of this journalism network.

First of all, we will provide a theoretical overview of different points of view, coming forward with classifications suggested by certain authors on different types of relationship established by connectors. Further, our argumentation will stay focused on relationships established in both versions (English and Albanian) and, at the same time, for the sake of identification of connectors establishing such relationships.

Statistical analysis, followed by functional and semantic analysis, will yield results on frequency of semantic relationships established by these connectors providing also numerical data on the most frequent connectors within the searched corpus.

\subsection{Literature review}

\subsubsection{Features of connectors as implementers of cohesion}

Connectors - denoting the subject matter of this paper - in addition to reference and substitution, are amongst those grammatical means that display grammatical cohesion, features denoting its classification into this subgroup as opposed to lexical cohesion that is implemented through vocabulary of a given language (Rugova \& Sejdiu-Rugova, 2015: 138).

Originally coined as a concept in 1976 by Halliday and Hassan as "a semantic relationship implemented through lexical-grammatical system", cohesion has been defined as a language tool, which is displayed and introduced whenever "the interpretation of some element in the discourse is dependent on that of another. The one presupposes the other, in the sense that it cannot be effectively decoded except by recourse to it" (Halliday \& Hassan, 1976: 4). Based on this, Rugova (2009: 149) concludes that this nexus "presupposed - presupposing" between different parts of the text that in turn gives meaning to such text, is actually cohesion itself.

By gaining more insight into the text linguistics study, new points of view and definitions have now emerged on cohesion, its function of the text as well as its implementation tools. Thus, in his work Linguistica testuale dell' italiano, the author Palermo (2015: 76) considers the coherence and cohesion to be the two fundamental forces that ensure survival of a given text, but not belonging to the same plan: a given text can be cohesive from its grammatical point of view, but yet deprived of its meaning and, vice versa, it can manifest visible gaps with respect to its grammatical cohesion, yet being comprehensible. In his view, cohesion is displayed as a supporting element of coherence that facilitates the text interpretation, but lacking sufficient autonomy on its own in order to assist realization of its communicative aspect within the text. In addition to this, apart from its cohesion function, Palermo (2015: 190), quoting the author Berretta (1984), considers connectors to be the promotors of demarcation function, given that these elements, along with the (spoken) intonation and (written) punctuation provide "organizational instructions" on the manner in which the producer is aiming to structure his/her text and relationship between its constituent parts. In other words, it is concluded by Palermo, that apart from preservation and structuration of parts of the text, connectors also define its architecture (ibid.). Similarly, Mingioni (2014: 9) argues that "a connector denotes a bridge between different units of the text, which are mutually linked through a semantically structured message." Such tool of achieving

\footnotetext{
$\dagger$ "Project Syndicate" is an international media organization that publishes and syndicates commentary and analysis on a variety of important global topics. All opinion pieces are published on the Project Syndicate website, but are also distributed to a wide network of partner publications for print. As of 2016, it has a network of 459 media outlets in 155 countries, taken from Wikipedia, the most recently accessed on 10.09.2017.
} 
cohesion, among other things, ensures realization of coherence, by embedding various types of logical and semantic relations between related segments.

Being the tools for realization of the logical continuity of the text, they have also been studied by Albanian scholars Dibra \& Varfi (1999: 88), highlighting their role in ensuring logical continuity of the text (i.e. the coherence itself) and being the tools found throughout the entire text, while exhibiting logical links between its parts (Ibid. 91).

\subsubsection{Grammatical features of connectors}

Speaking of different authors in the field of text studies, regardless diversity of their designations (Fraser, 2009: 294), nevertheless, uniformity can be seen amongst them when categorizing different parts of speech that are classified as connectors of the text. Therefore, given their morphological and syntactic features, connectors are seen as an open class (Berretta, 1984; Seriani, 1988, according to Palermo, 2015: 191), in the sense of being formed by numerous morphological categories, as well as in the sense that it is impossible to draft a fully comprehensive and final list. As to the grammatical point of view, it is the following grammatical classes that can be included and function as textual connectors

a) Conjunctions (coordinating, subordinating and conjunctional phrases: and, but, or, therefore, however, thus, whereas, because, in order to, etc.);

b) Adverbs and adverbial phrases (then, namely, after, before, yesterday, tomorrow, over there, it seems that, just, around, more or less, almost, consequently, initially etc.); ${ }^{\S}$

c) Interjections (eh, ah etc.);

d) Performative phrases (verbs) (say, reiterate etc.);

e) Complex phrases (for the beginning, differently from what we expected, as we could see, as predicted, closing this short panorama etc.).

The fact that the list of connectors is unfinished yet and as such it can be further expanded, can be best proven by the latest studies in the field of the text linguistics. So, in the classification made by Ferrari (2014: 132) in the volume "Linguistica del testo: Principi, fenomeni, strutture", we see an expansion of implementing categories of connectors with inclusion of nominal syntagmas and prepositions in adverbial functions (in ogni caso, per esempio, infatti, in particolare, etc.).

With respect to this, the aforementioned author draws attention to treating prepositions as textual connectors, since in her opinion "for a preposition to be a connector it should denote a relationship between events or between units of textual composition". She concludes that the variety of morphological features of connectors is reflected into variety of the syntactic elements and it is just this syntactic variety that determines the linguistic variety of the linked elements, which may be: syntagmas, subordinating phrases related with the main clauses, coordinating clauses, phrase groups (2014, p. 133).

\subsubsection{Classification of connectors and their semantic values}

In his article titled Pragmatic Connectives Van Dijk (1979: 447), when analyzing the pragmatic function of connectors, claims that semantic connectors express relations between denoted facts, whereas pragmatic connectors express relations between speech acts. Such a classification within the Italian domain is also provided by Bazzanella (1985), who also categorizes connectors into two distinct

\footnotetext{
‡ The above classification, but not the listing, is referred to the categorization made by the authors K. Dibra and N. Varfi in their book "Gjuhësi Teksti", 1999 :92.

$\S$ As it can be seen, the authors have also placed a number of words into this group, which had been traditionally categorized as particles, by not separating them as an independent subgroup.
} 
groups: semantic connectors and pragmatic connectors, which she refers to as "segnali discorsivi", while Palermo (2013: 191), argues that there are differences between them by concluding that "semantic connectors refer to the content of related segments, contributing to setting of hierarchical, logical and conceptual relations; pragmatic connectors display a number of functions referred to expression of the speaker's point of view not towards prepositional contents but rather towards what has been uttered or towards acts of speech".

Similar to that, also the author L. M. Stover (2016: 10), when referring to a number of authors who support argumentation of the DMs semantic features, in her thesis "Consecutive Connectors: A Study on Discourse Markers in Honduran Speech", cites the author Travis (2005: 2), who claimed that "the pragmatic use of discourse markers under consideration is semantically driven: the use of discourse markers is determined by their inherent meanings, which interacts with context-driven features to give rise to different pragmatic functions". Likewise, Blakemore (2002: 1) in introduction to her paper claims that "DMs are regarded as central to semantics because they raise problems for standard theories of meaning, and pragmatics because they seem to play a role in the way discourse is understood". From this, Stover concludes that "the difference between a pragmatic approach and a semantic approach to the study of DMs is that pragmatic approaches attempt to identify the functions with which markers are used and semantic approaches attempt to identify the meaning associated with those functions" (Ibid.).

Making reference to a classification made by a group of authors in the volume La Lingua e il Testo (1992), Dibra \& Varfi (1999: 92) reflect on categorization of connectors into three large groups, always considering their role in expressing different relationships in the text. Based on such categorization, we can distinct between the following types of connectors:

a) Logical connectors that express logical relationship linking different contents of text: time,

space, juxtaposition, expanding information, explanation, elaboration, conclusion;

b) Connectors that specify textual organization, which serve to guide and orientate the reader into the text structure;

c) Connectors that express the speaker's or writer's attitude.

According to Ferrari $(2005,2014)$, based on the semantic criterion, connectors may be categorized as per the type of logical relation they point to. And it is, precisely, the type of relation established by the connector the one that enables expression of its semantic value of: time, cause, consequence, permission, condition, juxtaposition, addition, dominance (It: dispositio).

In the modern Albanian tradition of studying connectors, authors Rugova \& Sejdiu-Rugova (2015: 147), considering peculiarities of the basic expression of connection in Albanian language, list the following five types of conclusion of the semantic relations: 1) linking or supplementary type; 2) juxtaposition or confrontation type; 3) causal type; 4) time type and 5) comparative type.

On the other hand, the author Mëniku (2013), in her doctoral thesis titled "Text connectors in Albanian language", initially provides a list of three main relationships between connectors: 1) supplementary relationship; 2) confrontational relationship and 3) causal relationship. She names the fourth group "Other Relationships" within which she then subgroups termination relationships, permission relationships, conditional relationships, and time connectors. For each and every relationship she has listed the respective implementing connector. 


\subsection{Research questions}

This study intends to answer the following research questions:

a) What kind of connectors could be identified from the selected corpus?

b) What kind of relationship do they establish?

c) What is the prevailing typology?

d) Which are the most frequently used connectors?

e) How such relationships are displayed in the translated version?

f) Has their functionality and positioning been faithfully preserved in the translated version?

g) Has the lexical-grammatical category of equivalent connectors been retained in both versions?

\section{Methodology}

The following methods will be applied: observational method, comparative method and statistical quantitative method.

Results of this research will be given based on the interpretative analysis that will be developed during the argumentation of the semantic features that characterize expressed relationships for each and every analyzed text, and subsequently, by generalizing the overall data we will be providing in the form of conclusions, also conclusions reached in the statistical plan.

\subsection{Data collection and analysis}

We will be comparing typology and relationships expressed by the connectors in some of the argumentative texts published in the investigative journalism Project Syndicate network with their analogous versions translated into Albanian and published in the Kosovo daily newspaper Koha Ditore.

The data used and collected in this study is based on the corpus data, which includes these five randomly chosen articles:

1. Esther Ngumbi: "Soil Science for a Hungry Planet”, Project Syndicate, 3 August 2017 /

"Shkenca e tokës për planetin e uritur”, "Koha ditore”, 7 August 2017.

2. Minxin Pei: “Did Liu Xiabo Die For Nothing”, Project Syndicate, 16 July 2017 /

“A vdiq për hiçgjë Liu Xiabo?”, "Koha ditore”, 22 July 2017.

3. Toni Blair: "The Egyptian Struggle and Beyond”, Project Syndicate, 11 July 2013 /

"Beteja egjiptiane dhe përtej saj”, "Koha ditore”, 14 July 2013.

4. Jean Pisany-Ferry: "The Politics of Moral Hazard”, Project Syndicate, 30 March 2013 /

"Politika e rreziqeve morale", "Koha ditore", 1 April 2013.

5. Jean Pisany-Ferry: “Solving Europe's Credibility Problem”, Project Syndicate, 30 September

2014 / "Zgjidhja e problemit të besueshmërisë së Evropës”, "Koha ditore”, 2 October 2014. 


\section{Results and discussions}

\subsection{Analysis of analogical semantic features of connectors in the researched corpus}

In the selected corpus, we were focused on argumentative texts belonging to the following fields: politics, economics (business, finance, political economy) environmentalism, international cultural relations \& social policies.

Generally speaking, in the first analyzed text ${ }^{* *}$, we notice a strict compliance of relationships expressed by analogous connectors. For instance:

(1) But one of the most powerful methods for increasing yields sustainably will come from leveraging what is already in the ground. (Juxtaposition relationship)

Mirëpo një prej metodave më të fuqishme për rritjen e qëndrueshmërisë së prodhimit buron prej baraspeshimit të asaj që aktualisht është mbjellë në tokë.

But we also found cases of replacement of connectors in translation not only with synonymous forms, but also in the semantic features they realize. As seen in the example below (2), the connector and, which mainly expresses a relationship of addition, was translated as the connector since, reflecting thereby motivation, semantic features that are categorized into causal relations:

(2) Feeding the world efficiently will not be easy, and intangibles such as climate change, violent conflict, and the availability of fresh water will complicate it further.

Sigurimi i ushqimit të mjaftueshëm për botën nuk do të jetë punë e lehtë, pasi që shoqëruar nga ndryshimet klimatike, konfliktet e dhunshme dhe mungesa e ujit të pastër do t'i komplikojnë edhe më shumë gjërat.

In the following examples (3) and (4) in Albanian version, in addition to the connector too (po ashtu), which denotes a relationship of illustration, or of course (natyrisht), which denotes a relationship of confirmation, the particle as well has been added as a confirmation connector:

(3) Big companies, too, are getting in on the act. (Relationship of addition - confirmation)

Edhe kompanitë e mëdha po ashtu po i hidhen kësaj pune.

(4) Universities are of course actively participating in microbial-related research as well.

Natyrisht edhe Universitetet po marrin pjesë aktivisht në kërkimet mikrobiale.

It can be noted from example (5) given below that the connector and was translated as connector whereas displaying thus a relation of juxtaposition between the two prepositions.

(5) The current market value for these products is $\$ 2.3$ billion, and the market is expected to grow to $\$ 5$ billion over the next four years.

Vlera aktuale në treg e këtyre produkteve është 2.3 miliardë dollarë, ndërsa pritet të rritet deri në 5 miliardë dollarë gjatë katër vjetëve të ardhshëm.

\footnotetext{
** "Soil Science for a Hungry Planet" is the first analyzed text, written by Esther Ngumbi and published in the "Project Syndicate" on 3 August 2017 and republished in Albanian in "Koha ditore", on 7 August 2017. It was classified under the Section "Sustainability \& Environment".
} 
The next example (6) is characterized by the presence of two connectors: but in English, which expresses a relationship of juxtaposition and since in Albanian, which in the original version is represented by the preposition with, which in one of its numerous meanings corresponds with conjunctional locution given that displayed in the translated version with its synonymic form since denoting expression of motivational causal relationships ${ }^{\dagger \dagger}$ :

(6) But research on African soil microbes remains limited, // with most microbial solutions being developed for Western markets. (Relationship of juxtaposition)

Mirëpo kërkimi për mikrobet tokësore të Afrikës mbetet i kufizuar, pasi që shumica e zgjidhjeve mikrobiale po zhvillohen për tregjet perëndimore.

A similar situation is encountered in the following example (7). Preposition with in the original version was translated with an equivalent semantic variant while expressing thereby relationship of time parallelism:

(7) My own work on soil microbes at Auburn led to the issuance of three US patents, // with several agricultural companies pursuing the rights to commercialize products from the technology.

Vetë punimet e mia në mikrobet e tokës në Auburn hapën rrugën në sigurimin e tri patentave amerikane,

ndërkohë që edhe disa kompani të tjera bujqësore po kërkojnë të drejta për tregtimin e prodhimeve me anë të teknologjisë.

Consequently, out of 22 cases of semantic connectors identified in this text, we conclude that only in three cases the Albanian translation variants express different relationship when compared to the original version.

Also in the second text ${ }^{\star *}$, it can be seen that the semantic equivalents were retained in both variants, even though we came across some discrepancy cases between the original and translated versions and usage of respective connectors. In the next example (8), we see that the connector but is missing, although it is clearly implied due to contextual relation of juxtaposition, while the same connector is present in Albanian translation in another synonymic form yet.

(8) //The CCP remains a political behemoth, with nearly 90 million members, and its capacity to defend its

power is vast. (Elliptic relationship of juxtaposition / relationship of addition)

$\underline{\text { Ama } C C P-j a ~ m b e t e t ~ n j e ̈ ~ m o n s t e ̈ r ~ p o l i t i k e, ~ m e ~ p o t h u a j s e ~} 90$ milionë anëtarë, dhe me kapacitetin marramendës për ta mbrojtur pushtetin e vet.

In the translated version, as it can be seen in the next example (9), conditional relationship is expanded with the use of resulting connector then, giving the successive connector features of expression of the logical conclusion of the argument put forward. This connector is not found in the original version, leaving the logical conclusion implied. Also, the use of the connector and accompanied with the adverb thus (in this manner) justifies expression of the relationship of consequence between connectors.

(9) If protectionism takes hold in China's key overseas markets, // the country's economic prospects - and thus the CCP's legitimacy - could quickly decline. (Conditional relationship / resulting relationships not

\footnotetext{
${ }_{\dagger}$ For more semantic sequences of the preposition with see: A. S. Hornby, Oxford Advanced Learner's Dictionary of current English, Oxford University Press, 1989: 1468.

\# “Did Liu Xiabo Die For Nothing” was written by Minxin Pei exclusively for the investigative journalist network Project Syndicate and was published on 16 July 2017. Its Albanian translation was published in Koha Ditore, on 22 July 2017.
} 
expressed in the original version / additional conclusion relationships)

Nëse proteksionizmi i merr nën kontroll tregjet kryesore kineze përtej detit, atëherë gjasat ekonomike të shtetit - dhe kësisoj edhe vetë legjitimiteti i CCP-së-mund të shënojnë rënie të shpejtë. (Then= resulting relationship)

In the third argumentative text ${ }^{\S \S}$, both versions display analogous usage of connectors. There are very few cases (only two of them out of 50 identified connectors), in which we noticed expansion of connectors with intensifying particles or usage of a connector when the latter is clearly implied in the context of the original version.

Although it does not appear in the original version (10), the translated version does contain the particle only, whose role is only to intensify a premature time sequence.

(10) A few weeks back, I met the tourism minister, who I thought was excellent and had a sensible plan to revive the sector. (Time relationship / relationship of addition)

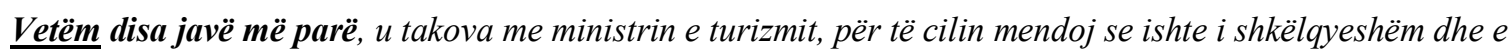
kishte një plan të prekshëm për ta ringjallur sektorin.

In the next example (11), we have a usage of the connector after, in the role of implementer of the time relationship of lateness, yet vested with causal nuances, imposed by the content of the motivating connector; also the time connector a few days later displays parallel time relationship with the connector of the preceding paragraph a few weeks back. The same typology was also retained in the translation:

(11) A few days later, he resigned, after Morsi took the mind-boggling step of appointing as Governor of Luxor province (a key tourist destination) someone who was affiliated with the group responsible for the terrorist attack in 1997 - Egypt's worst ever - in which more than 60 tourists in Luxor were killed.

Disa ditë më vonë, ai dha dorëheqje, pasi Morsi e ndërmori një hap të paparamendueshëm për ta emëruar si prefekt të krahinës Luxor (një destinacion kyç turistik) dikë që ishte i afërt me grupin përgjegjës për sulmin terrorist të vitit 1997 - më i rëndi ndonjëherë në Egjipt - në të cilin jetët humbën 60 turistë në Luxor.

(12) Democracy is a way to decide who the decision-makers will be, // not a substitute for making decisions.

Demokracia është një mënyrë për të vendosur se kush do të jenë vendimmarrësit, e jo një zëvendësim për marrjen e vendimeve.

In the example given above (12), there is a lack of additional connector and in the original version, which is typical for non-conjunctional sentences, while this same connector is found in the translation, realizing thereby expansion of argumentation. Also in the next example (13), the original version contains the additional connector and, which semantically speaking displays a relationship of juxtaposition, whereas in Albanian translation it is realized through the typical juxtaposition conjunction while.

(13) A protest is not a policy; and a placard is not a program for government. (Relationship of juxtaposition)

Një protestë nuk është një politikë; ndërsa një pankartë nuk është një program për qeverinë.

$\S \S$ "The Egyptian Struggle and Beyond" was written by Tony Blair exclusively for the investigative journalist network Project Syndicate, under the section World Affairs Culture \& Society Politics and was published on 11 July 2013. Its Albanian translation was published in Koha Ditore, on 14 July 2013. 
Analysis of the semantic values of the used connectors in the fourth argumentative text ${ }^{* * *}$ proves that relations were retained in both versions. In the translated versions there are two interesting cases of usage of connectors.

(14) Immediately after this declaration, however, prices of European bank stocks plunged, and Dijsselbloem

was accused by many (including some of his colleagues) of having poured oil on a burning fire.

Megjithatë, menjëherë pas kësaj deklarate, çmimet e aksioneve të bankës evropiane pësuan rënie dhe

Dijsselbloem u akuzua nga shumë (përfshirë nga disa prej kolegëve të tij) se i kishte hedhur vaj zjarrit që

digjej.

In the example above (14), in both versions, the connector however (megjithatë) displays a relationship of juxtaposition that is strengthened by the usage of the time connector immediately (menjëherë) + prepositional syntagm after this declaration (pas kësaj deklarate). Yet, if we are to look closely at the translated version we see a displacement of the juxtaposition connector however from the middle of the connector to its beginning in anticipation of rather contradictory character expressed during argumentation of the author. In addition to this, a relationship of addition realized through the connector and contributes to expansion of the textual argumentation.

In the next example (15), the original version contains at the beginning the connector but, which displays a relationship of juxtaposition which is further strengthened during argumentation by the connector nonetheless. On the other hand, the Albanian translation does not retain the structure of the connector but, shrinking thereby the substantial preposition in expression of the relationship of permission through the connector sidoqoftë (nevertheless).

(15) But its abrogation would nonetheless be symbolically powerful, sparking anxiety throughout Europe.

Sidoqoftë, gjendja e tillë ka shkaktuar shqetësim në mbarë Evropën.

Quite interesting are also the examples encountered in the last analyzed argumentative text ${ }^{\text {tit }}$.

(16) As the Eurozone debates how to escape the stagnation trap in which it finds itself, one question has become increasingly important: Can governments credibly commit to trim public spending in the future while avoiding immediate cuts?

Në kohën kur eurozona po debaton se si të dilet prej kurthit të ngecjes në të cilin është zhytur vetë, një pyetje është bërë shumë e rëndësishme: A munden qeveritë të reduktojnë me besueshmëri shpenzimet publike dhe njëkohësisht të plotësojnë boshllëqet e shkaktuara?

In the example above (16) we conclude that typology of relationship expressed by the connector as in the original version was also retained in the translation, yet instead of using the time connectors ndërsa (whereas) / teksa (while) (that would analogically correspond to the original version) we come across the other connector në kohën kur (at the time when), which is a conjunctional locution. Hence, unlike the original version that does not have to contain the additional connector and, the translated version - due to coordination order of connectors, makes use of the connector dhe (and) that supplements expansion of author's argumentation.

\footnotetext{
*** "The Politics of Moral Hazard" was written by Jean Pisany-Ferry exclusively for the investigative journalist network Project Syndicate, under the section "Business \& Finance Economic Politics" and was published on 30 March 2013. Its Albanian translation was published in Koha Ditore, on 1 prill 2013.

it广 "Solving Europe's Credibility Problem" was written by Jean Pisany-Ferry exclusively for the investigative journalist network Project Syndicate, under the section "Politics Economics" and was published on 30 September 2014. Its Albanian translation was published in Koha Ditore, on 2 October 2014.
} 
In the next example (17), we conclude lack of usage of the permission connector edhe pse/ ndonëse/ megjithëse (though/ although/ even though) in the translated version, in the same manner as it was used in the original version. Boosting particle edhe (and) is therefore considered to be redundant in this case for expression of permission relationship.

(17) Though monetary policy is supportive, it is close to reaching its limits, and the ECB's initiative to stimulate credit by lending to commercial banks on super-cheap terms has not proved as effective as hoped. (Relationship of permission/ addition/ comparison)

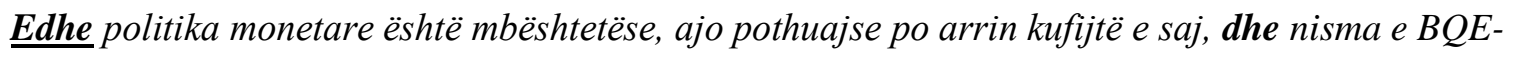
së për stimulim të kredive nëpërmjet huazimit të bankave tregtare me kushte të favorshme ka dalë se nuk ishte efektive, sikur ishte menduar.

Finally, in the next example (18), the translated version contains shrinking information given in the original version, ending thus in dropping of the juxtaposition connector but.

(18) Its surveillance apparatus [is mostly used to monitor budget deficits in real time], but it could also help to evaluate the future consequences of policy decisions. (Relationship of intensified juxtaposition)

Aparati për monitorimin e politikave buxhetore të vendeve mund të ndihmojë edhe për vlerësim të pasojave të ardhshme të vendimeve politike.

If we are to refer to the degree of display of the relationship type expressed by analyzed connectors, we will find out that within the range of the semantic relationships identified, those with the highest frequency are the following: a) Relationship of addition present in 49 cases of their realization or in $29.52 \%$ of the total number of expressed relationships, meaning that these relationships make up roughly one-third of all the semantic relationships; b) Relationship of juxtaposition displayed in 35 cases or in $21.08 \%$ of the total number, a value corresponding to an average of one fifth of the total established relationships; and c) Relationship of time in 32 cases or in $19.28 \%$ of them corresponding to approximately one fifth of the total number of relationships analyzed. The respective graph will be presenting exactly these processed data, confirming the aforementioned prevailing relationships.

Table 1. Frequency of the semantic relationship typology

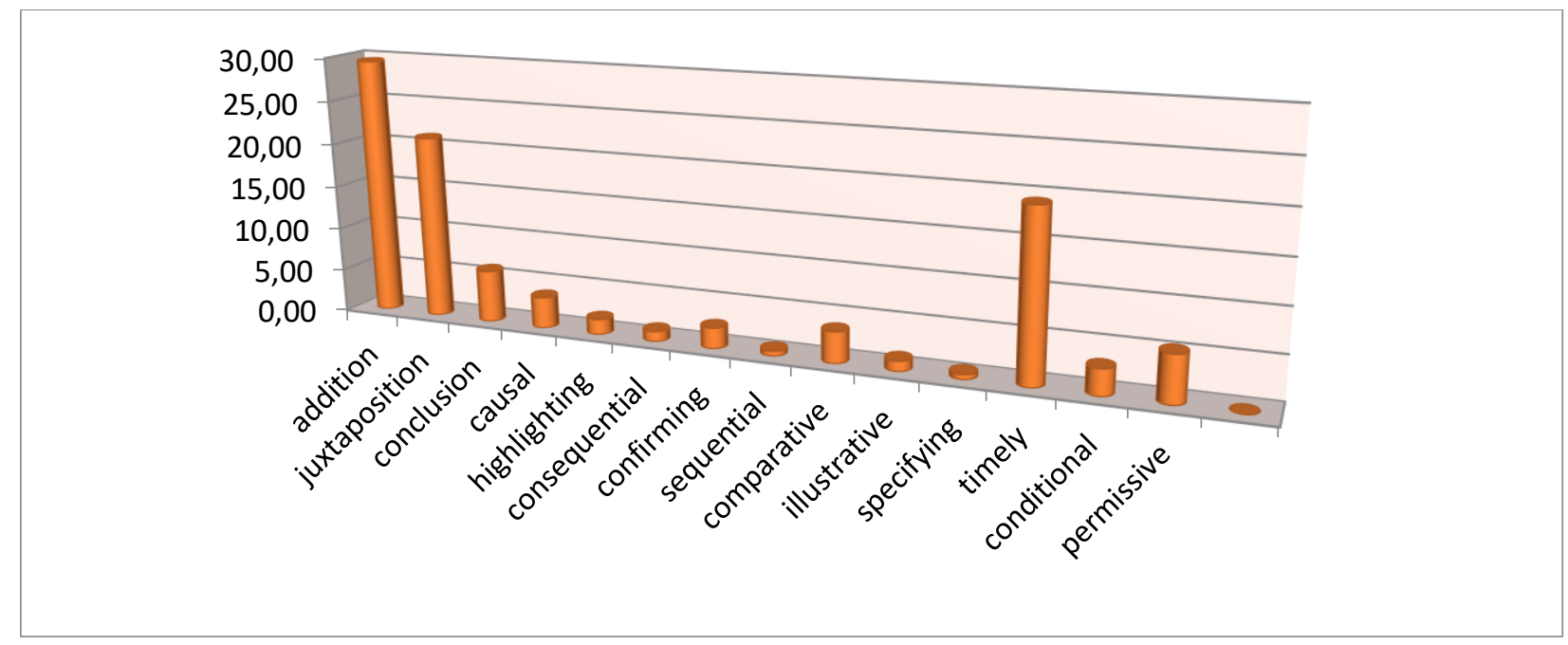




\section{Conclusions}

Connectors being the tools that functionally realize textural connectivity, may exhibit quite interesting features in the text structure. As reasoned above, they are parts of an open and heterogeneous class (conjunctions, particles, adverbs, etc.) that play quite an important role at both logical and semantic level in addition to the pragmatic level of the text.

In this study, we were focused on addressing the connectors identified in the argumentative texts, analyzing them in the comparative ratio between the two versions (English and Albanian). Within the range of the identified semantic relationships, the most frequent ones are the relationships of addition with $29.52 \%$ of the total number of relationships expressed, followed by the relationships of juxtaposition with $21.08 \%$ and by the relationships of time with $19.28 \%$ of all examined relationships.

Also in the translated versions, a strict compliance of relationships expressed by analogous connectors can be generally noted. Nonetheless, we also found cases of substitution of connectors with synonymic forms not only in translated forms, but also with display of semantic features, too. It is a characteristic feature of the original and translated version for the connector and, which typically exhibits relationship of addition (in 31 out of 40 cases, two of which are rather intensified by nuances of conclusion: and, precisely, and thus), to also appear displaying a relationship of juxtaposition (in 6 out of 40 cases, when it corresponds to the analogous forms whereas, while), as well as displaying a relationship of condition (in two cases, realized analogically by the conjunctional locution since). Concerning the use of the preposition with in the original version, there are basically two corresponding conjunctional locutions in the translated version, namely since and while at the meantime, which display a relationship of condition and time, respectively. Such use marks one the less common cases of implementation of connectivity in the translated text by means of different lexical - grammatical categories from the original version.

As far as their topic is concerned, generally speaking, both variants display a strict compliance with their positioning. An exception to this conclusion is provided by example (14), which in the translated version shows a displacement of connectors at the beginning of prepositions, enabling thereby realization of respective relations, which are enhanced by different nuances.

For sure, the manner in which this paper has tackled the issue of connectors and their mutual relationship, constitutes a humble step towards a more in-depth and analytical treatment in different types of texts, in order to provide a wider spectrum of their functional argumentation.

\section{References}

Bazzanella, C. (1985). L'uso dei connettivi nel parlato: alcune proposte, në A. Franchi De Bellis e L. M. Savoia. Sintassi e morfologia della lingua italiana d'uso. SLI. Roma. Bulzoni, 83-93.

Berreta, M. (1984). Connettivi testuali e pianificazione del discorso, in Coveri et al., 237- 254.

Blakemore, D. (2002). Relevance and linguistic meaning: The semantics and pragmatics of discourse markers. Cambridge: Cambridge University Press.

Dibra, K. \& Varfi, N. (1999). Gjuhësi Teksti. Tiranë: SHBLU.

Ferrari, A. (2014). Linguistica del testo. Principi, fenomeni, strutture. Roma. Carocci.

Fraser, B. (1996). Pragmatic markers. Pragmatics 6 (2), 167-190.

Fraser, B. (2009). An account of Discourse Markers. International review of Pragmatics 1, 293-320. 
Halliday, M.A.K. \& Hasan, R. (1976). Cohesion in English. London: Longman.

Hornby, A. S. (1998). Oxford Advanced Learner's Dictionary of current English. Oxford University Press (Fourth Edition).

Mingioni, I. (2014). Aspetti formali e semantico-pragmatici dei connettivi di chiusura del discorso in prospettiva storica e sincronica. Disertacion i doktoratës. Università Roma Tre \& Universität Basel.

Mëniku, L. (2013). Konektorët e tekstit në gjuhën shqipe. Disertacion i doktoratës. Universiteti i Tiranës.

Palermo, M. (2015). Linguistica testuale dell' italiano. Bologna. Il Mulino.

Rugova, B. \& Rugova -Sejdiu, L. (2015). Hyrje në gramatikën e tekstit. Prishtinë: Trembelat.

Rugova, B. (2009). Gjuha e gazetave. Prishtinë: Koha.

Stover, L. M. (2016). Consecutive Connectors: A Study on Discourse Markers in Honduran Speech. LSU. Master's Theses. 35.

Travis, C. E. (2005). Discourse markers in Colombian Spanish: A Study in polysemy.

Van Dijk, T.A. (1979). Pragmatic Connectives. Journal of Pragmatics 3, 447 - 456.

\section{İngilizce ve Arnavutça tartışmalı metinlerdeki bağlayıcıların anlamsal ilişkilerinin karşılaştırmalı analizi}

\section{$\ddot{O} z$}

Bu yazının asıl amacı, metin bağlantılarının sadece yerel değil küresel bağlamda da uygulanabilmesi için araç olarak metin bağlayıcıların işlevsel analizi ve tartışılmasıdır. Bu yazının karşılaştırmalı niteliği göz önüne alındığında, araştırmacı gazetecilik Project Syndicate ağında yayınlanan bazı argümanlı metinlerde bağlayıcıların ifade ettiği tipoloji ve ilişkileri, Arnavutça'ya çevrilmiş ve Kosova günlük gazetesi Koha Ditore'de yayınlanan analog versiyonlarıyla karşılaştıracağız.Bu nedenle, ifade ettikleri ilişkilerin tedavisi, çeviri sürecinde bağlayıcı tipolojisinin, çevrildikleri dilin orijinal varyantlarından Arnavutça'da bizim çevremizdeki korunmalarını analiz ederek gerçekleştirilecektir.Bu tür işlenmiş veriler, bağlayıcıların kullanım sıklığı, gerçekleşme yolları, bağlayıcıların yaygınlığına göre ifade edilen ilişkiler, bunların anlamsal, dilbilgisi ve işlevsel denkliği ile ilgili cevaplar sağlayacaktır.

Anahtar Kelimeler: Metinsel bağlanabilirlik; bağlayıcılık; ilişkilerin tipolojisi; göreceli frekans; tartışmacı metin

\section{AUTHOR BIODATA}

Manjola Lubishtani is an assistant in Albanian language at the English Language Faculty, AAB University in Prishtina. She received her MA degree in Linguistics from University of Prishtina "Hasan Prishtina" and actually is a PhD cand. in Linguistics at the same university. She is interested in applied linguistics, semantics, pragmatics and text linguistics. 